\title{
Silencing $\beta 1$,2-xylosyltransferase in transgenic tomato fruits reveals xylose as constitutive component of lgE-binding epitopes
}

\section{Kathrin Elisabeth Paulus ${ }^{1}$, Vera Mahler ${ }^{2}$, Martin Pabst ${ }^{3}$, Karl-Heinz Kogel $^{4}$, Friedrich Altmann ${ }^{3}$ and Uwe Sonnewald ${ }^{1 *}$}

1 Department of Biology, Friedrich-Alexander-University Erlangen-Nuremberg, Erlangen, Germany

2 Department of Dermatology, University Hospital Erlangen, Friedrich-Alexander-University Erlangen-Nuremberg, Erlangen, Germany

${ }^{3}$ Department of Applied Genetics and Cell Biology, University of Natural Resources and Life Science, Vienna, Austria

${ }^{4}$ Research Centre for BioSystems, Land Use and Nutrition, Justus Liebig University Giessen, Giessen, Germany

\section{Edited by:}

Vincent Bulone, Royal Institute of Technology, Sweden

\section{Reviewed by:}

Vincent Bulone, Royal Institute of Technology, Sweden

Chen Hongzhang, Chinese Academy of Sciences, China

\section{${ }^{*}$ Correspondence:}

Uwe Sonnewald, Department of Biology, Friedrich-Alexander University Erlangen-Nuremberg, Staudtstrasse 5, 91058 Erlangen, Germany.

e-mail: usonne@biologie.uni-erlangen.de
Complex plant $\mathrm{N}$-glycans containing $\beta 1,2$-xylose and core $\alpha 1,3-f u c o s e$ are regarded as the major class of the so-called "carbohydrate cross-reactive determinants" reactive with IgE antibodies in sera of many allergic patients, but their clinical relevance is still under debate. Plant glycosyltransferases, $\beta 1,2-x y l o s y l t r a n s f e r a s e ~(X y I T)$, and core $\alpha 1,3$-fucosyltransferase (FucT) are responsible for the transfer of $\beta 1,2$-linked xylose and core $\alpha 1,3$-linked fucose residues to $\mathrm{N}$-glycans of glycoproteins, respectively. To test the clinical relevance of $\beta 1,2$-xylose-

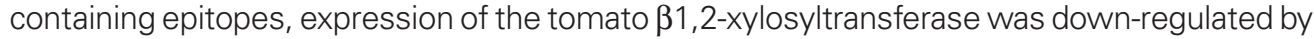
RNA interference (RNAi) in transgenic plants. Fruits harvested from these transgenic plants were analyzed for accumulation of XyIT mRNA, abundance of 31,2 -xylose epitopes and their allergenic potential. Based on quantitative real-time PCR analysis XyIT mRNA levels were reduced up to 10-fold in independent transgenic lines as compared to untransformed control, whereas no xylosylated $\mathrm{N}$-glycans could be revealed by MS analysis. Immunoblotting using anti-

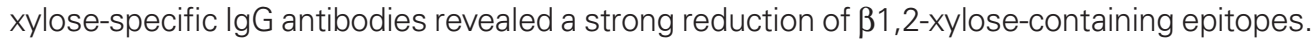
Incubating protein extracts from untransformed controls and XyIT_RNAi plants with sera from tomato allergic patients showed a patient-specific reduction in IgE-binding, indicating a reduced allergenic potential of XyIT_RNAi tomato fruits, in vitro. To elucidate the clinical relevance of

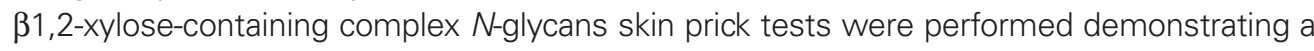
reduced responsiveness of tomato allergic patients, in vivo. This study provides strong evidence for the clinical relevance of $\beta 1,2$-xylose-containing epitopes in vivo.

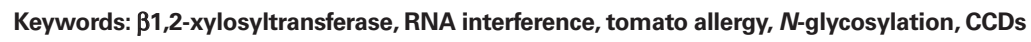

\section{INTRODUCTION}

In the last years an increase of allergic diseases could be observed. Prevalence of food allergy is highest in infants (6-8\%) and decreases slightly with age, affecting almost $4 \%$ of the adults (Cianferoni and Spergel, 2009). In most studies on allergic manifestations post-translational modifications like glycosylation of the allergenic proteins were not taken into account. The term "glycosylation" describes the covalent linkage of an oligosaccharide side chain to a protein. In most glycoproteins the oligosaccharide chain is attached to the amide nitrogen of an asparagine (Asn) residue ( $\mathrm{N}$-glycosylation) and/or to the hydroxyl group of threonine (Thr), serine (Ser), or hydroxylproline (Hyp; O-glycosylation) residues of the peptide backbone (Saint-Jore-Dupas et al., 2007). The protein N-glycosylation starts in the endoplasmic reticulum (ER) with co-translational transfer

Abbreviations: CCDs, carbohydrate cross-reactive determinants; CmR, chloramphenicol resistance; $\mathrm{Cv}$, cultivar; ECL, enhanced chemiluminescence; mRNA, messenger RNA; OCS, octopine synthase terminator; PNGase A, peptide- $N$-glycosidase A; qPCR: quantitative real-time PCR; RNAi, RNA interference; SDS-PAGE, sodium dodecyl sulfate-polyacryl-amide gel electrophoresis; SPT, Skin prick test; TBS: trisbuffered saline; WT, wild type; XylT, $\beta 1$,2-xylosyltransferase. of an oligosaccharide precursor, $\mathrm{Glc}_{3} \mathrm{Man}_{9} \mathrm{GlcNAc}_{2}$, onto specific Asn residues. After the transfer onto the nascent protein and during glycoprotein transport along the secretory pathway, $\mathrm{N}$-linked oligosaccharides undergo several maturation steps involving the removal of glucose (Glc) and Mannose (Man) residues to generate highmannose type $\mathrm{N}$-glycans and the addition of new sugar residues in the ER and the Golgi apparatus, to generate complex type $N$-glycans (Gomord and Faye, 2004; Saint-Jore-Dupas et al., 2007). Up to now three major types of $\mathrm{N}$-glycans have been described in plants, the high-mannose-, the hybrid-, and the complex type (Foetisch and Vieths, 2001). The high-mannose type $N$-glycans contain five to nine mannose residues and no further sugar residues. In $\mathrm{N}$-glycans of the complex type $\beta$-mannose is substituted by a bisecting $\beta 1,2$-xylose and/or the proximal $\mathrm{N}$-acetylglucosamine of the core is substituted by a $\alpha 1,3$-fucose.

The $\beta 1,2$-xylose and the $\alpha 1,3$-fucose residues are not present in mammals and therefore constitute IgE-binding epitopes for carbohydrate reactive antibodies. The two main motifs, xylose and the core-3-linked fucose, form two essentially independent epitopes (Altmann, 2007). Plants contain both epitopes, insect glycoproteins 
only fucose. Their allergenicity and clinical relevance have been discussed for years (Tretter et al., 1993; van Ree et al., 2000; Bencurova et al., 2004). They are regarded as the major class of the so-called "carbohydrate cross-reactive determinants" (CCDs; Wilson and Altmann, 1998) reactive with IgE antibodies in the sera of many allergic patients (Strasser et al., 2004), however their clinical relevance is still under debate. Structurally similar CCDs are present in many plants and invertebrates. CCD-specific IgE antibodies may bind to several of them in unrelated species which often contributes to false-positive results in vitro when only CCD-specific IgEs bind to extracts and allergens (van Ree et al., 2000; Foetisch et al., 2003; Mahler et al., 2006; Altmann, 2007).

In addition, larger complex type plant $N$-glycans were identified containing additional $\beta 1,3$-galactose and $\alpha 1,4$-fucose residues linked to the terminal $\mathrm{N}$-acetylglucosamine units. These $\mathrm{N}$-glycans are known as Lewis a antigens and are usually found on cell surface glycoconjugates in mammals (Fitchette-Lainé et al., 1997; Melo et al., 1997). In the meantime, Lewis a epitopes were also found in many plant extracts and constitute another possible source of cross-reactivity (Foetisch and Vieths, 2001).

Some studies concerning the production of therapeutic proteins in plants circumvent the problem of plant specific glycosylation by silencing the glycosyltransferases XylT and FucT, which are crucial for transferring the representative sugar residues to glycoproteins (Strasser et al., 2004; Cox et al., 2006). Strasser et al. (2008) were able to modulate the $\mathrm{N}$-glycan composition in Nicotiana benthamiana by simultaneous silencing of FucT and XylT. Using XylT/FucT silenced transgenic plants for transient expression of the human anti-HIV monoclonal antibody $2 \mathrm{G} 12$, the plant-made antibody contained an almost homogeneous $\mathrm{N}$-glycan species without detectable $\beta 1,2$-xylose and $\alpha 1,3$-fucose residues.

Here, we report on the successful modulation of $N$-glycosylation in transgenic tomato plants. To generate hypo-allergenic tomato fruits and to test the clinical relevance of $\beta 1,2$-xylose, the gene coding for $\beta 1,2$-xylosyltransferase was down-regulated by RNA interference (RNAi) in transgenic tomato plants. The allergenic potency of transgenic XylT_RNAi tomato fruits was analyzed by different molecular tests. The XylT_RNAi lines exhibited a successful inhibition of XylT expression in the transgenic tomato plants. The accumulation of the XylT transcript was 10-fold less compared to untransformed samples. On the basis of IgE immunoblotting assays XylT_RNAi tomato fruits revealed a patient-specific reduction in IgE reactivity, indicating a reduced allergenic reactivity in vitro caused by the XylT suppression. Furthermore, patients with tomato allergy had reduced mean wheal diameters in skin prick tests (SPT), demonstrating a reduced allergenic potential of XylT_RNAi tomato fruits in vivo.

\section{RESULTS \\ RNAI-MEDIATED SILENCING OF $\beta 1,2$-XYLOSYLTRANSFERASE EXPRESSION IN FRUITS OF TRANSGENIC TOMATO PLANTS}

To achieve down-regulation of XylT expression in transgenic tomato plants, a $475 \mathrm{bp}$ fragment of the coding sequence of XylT was cloned in sense and antisense-orientation into the vector pK7GWIWG2(II; Karimi et al., 2002) in order to create the final transformation plasmid pK7GWIWG2-XylT (Figure 1A). The binary RNAi construct was used for Agrobacterium tumefaciens mediated transformation of the tomato var. MicroTom. A total of 24 kanamycin-resistant tomato plants (referred as XylT_RNAi plants) were generated. The XylT_RNAi tomato plants were subsequently analyzed on the mRNA level to validate the degree of silencing. For quantitative real-time PCR ( $\mathrm{qPCR}$ ) analysis the total RNA was extracted from tomato fruits and $4 \mu \mathrm{g}$ of the RNA were translated into cDNA. Figure 1B shows the relative expression of XylT mRNA in tomato fruits from wild type (WT) and individual plants of the T1-generation of XylT_RNAi lines 3, 9, and 12. The relative expression levels of the different transgenic lines varied. Compared to the untransformed control, XylT transcript levels were reduced 83\% (line 3), 76\% (line 12), and 20\% (line 9), respectively.

\section{SILENCING OF THE $\beta 1,2$-XYLOSYLTRANSFERASE LEADS TO A STRONG REDUCTION IN $\beta 1,2$-XYLOSE-CONTAINING EPITOPES OF GLYCOPROTEINS}

For the detection of $\beta 1,2$-xylose-containing $N$-glycans, protein extracts from XylT_RNAi, and WT tomato fruits were subjected to immunoblot analysis. Protein extracts of fruits were separated on sodium dodecyl sulfate-polyacrylamide gel electrophoresis (SDSPAGE) and blotted onto nitrocellulose membranes. For immunodetection of xylose residues, a xylose-specific IgG antibody was used. In protein extracts from fruits of untransformed WT controls, binding of the anti-xylose antibodies to several proteins could be detected, indicating the presence of different proteins carrying $\beta 1,2$ xylose epitopes (Figure 2A). Binding of the anti-xylose antibodies to proteins from fruits of XylT_RNAi plants was undetectable or

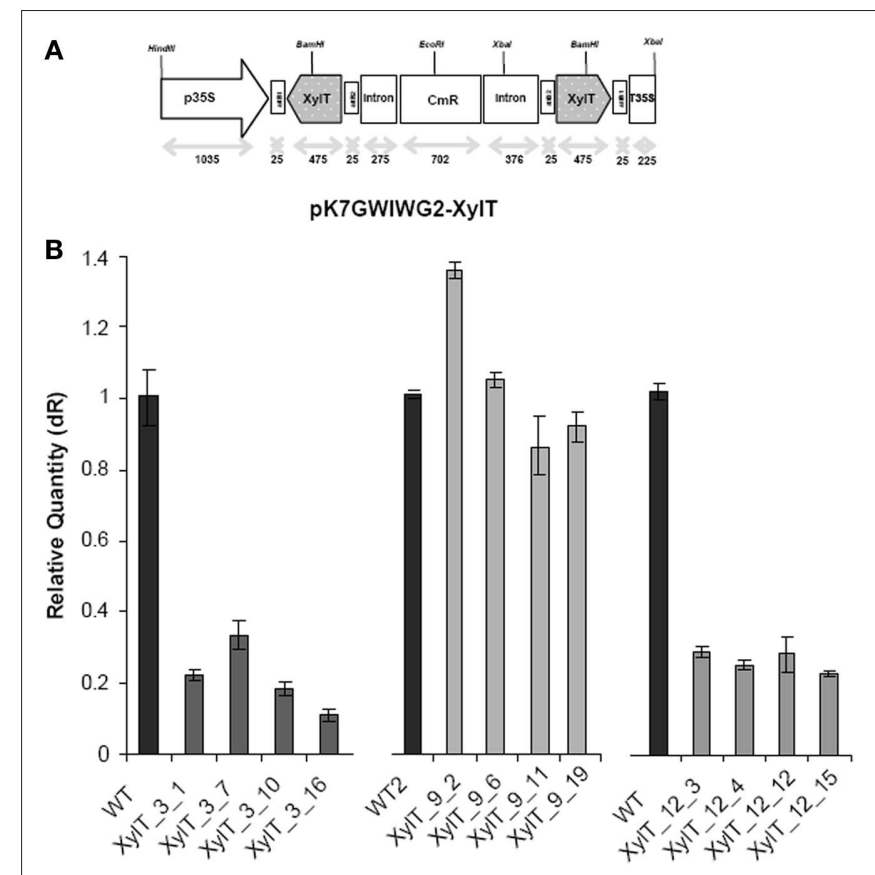

FIGURE 1 | Silencing of XyIT expression in transgenic tomato plants. (A) Scheme of the XylT_RNAi construct (XylT in sense and antisense orientation). p35: 35S cauliflower mosaic virus promoter; T35S: terminator; attB1, attB2: recombination sites; $\mathrm{CmR}$ chloramphenicol acetyltransferase gene. (B) qPCR of three selected transgenic lines with reduced XylT expression. Total RNA of green fruits was extracted and $4 \mu \mathrm{g}$ of total RNA were reversed transcribed. The resulting cDNA was used as template for qPCR analysis. 
strongly reduced, indicating the lack of xylose residues (Figure 2A). To ensure the equal amounts of protein a silver stained SDS-gel was used as loading control (Figure 2B).

To further characterize the $N$-linked oligosaccharides, protein extracts from XylT_RNAi fruits were tested by ConA-affinoblotting. ConA binds to high-mannose (alpha-D-mannosyl groups at the non-reducing terminus of oligosaccharides) but not to complex $N$-glycans and therefore allows distinguishing both $N$-glycans. As shown in Figure 3A, ConA binding to a number of glycoproteins can be detected in control extracts. In extracts from red fruits of two independent XylT_RNAi lines, 3 and 12, ConA binding to glycoproteins was strongly enhanced. Since the total amount of protein per lane was equal (Figure 3B) this observation suggests that abolishing XylT activity enhances the occurrence of high-mannose type $N$-glycans. In view of the fact that complex $N$-glycans not only carry $\beta 1,2$-xylose but also $\alpha 1,3$-fucose residues, glycoproteins of WT and XylT_RNAi lines were analyzed for the presence of both sugar moieties using anti-xylose and anti-fucose antibodies, respectively. As shown in Figure 4, strong reduction in xylose-containing epitopes (Figure 4A) in green (Figure 4, lanes 1-3), orange (Figure 4, lanes 4-6), and red (Figure 4, lanes 7-9) tomato fruits is paralleled by a slight reduction of fucose-containing epitopes (Figure 4B). To clarify the observed changes in $N$-glycan composition the $N$-glycosylation profile of WT and XylT_RNAi lines 3 and 12 was determined by LC-ESI-MS analysis. The mass spectrum of WT plants revealed that the vast majority of the $N$-glycan species carried xylose and $\alpha 1,3$-fucose residues. The XylT_RNAi lines exhibited a complete loss of $\beta 1,2$-xylosylated $N$-glycans. The XylT knock-down lines, only contained either core $\alpha 1,3$-fucosylated structures (MMF, $\mathrm{MGnF}_{\text {iso' }}$, $\mathrm{GnGnF}$ ) or glycans devoid of any of the two plant-typical immunogenic determinants (Figure 5). At this point it should be highlighted that all XylT_RNAi lines were viable and did not exhibit any obvious phenotype under standard growth conditions (data not shown).
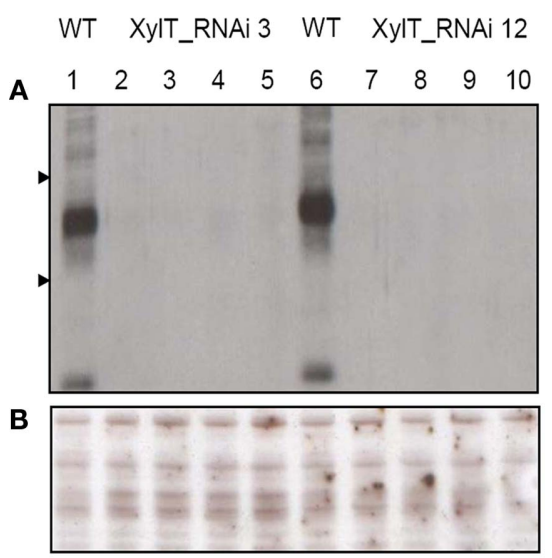

FIGURE 2 | Detection of xylose-containing $\boldsymbol{N}$-glycans in protein extracts from transgenic XyIT_RNAi and wild type tomato fruits. (A) Immunoblot analysis of $\beta 1,2$-xylose-containing $N$-glycans of WT (lane 1 and 6 ) and independent T2 plants of XylT_RNAi line 3 (lanes 2-5) and XylT_RNAi line 12

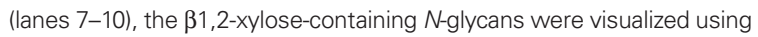
anti- $\beta$-1,2-xylose-specific antibodies. Protein standards of 55 and $36 \mathrm{kDa}$ are represented by arrow heads. (B) SDS-PAGE and silver staining of protein extracts from green fruits.

\section{REDUCED ALLERGENIC POTENCY OF XYIT_RNAi TOMATO FRUITS IN VITRO DETERMINED BY IgE IMMUNOBLOTTING}

Three symptomatic tomato allergic patients with a specific IgEbinding to a $52 \mathrm{kDa}$-protein were recruited to test their in vivo allergic reactivity to XylT-reduced tomato fruits. Sera of these patients were used for further in vitro IgE immunoblotting and CAP FEIA (UniCAP 100, Phadia, Freiburg, Germany) analysis. Table 1 shows the demographic data, allergic symptoms and the patient history as well as specific IgE levels of all investigated patients. Representative IgE-binding patterns to total soluble proteins from WT and XylT_RNAi tomato fruits are shown in Figure 6. For the IgE immunoblot analysis, protein extracts of WT (Figure 6, lane 1) and XylT_RNAi lines 3 (Figure 6, lane 2), 9 (Figure 6, lane 3), and 12 (Figure 6, lane 4) were separated on SDS-PAGE and subsequently blotted onto nitrocellulose membranes. The membranes were first incubated in diluted patient's serum, and then transferred into a diluted anti-human IgE antibody, conjugated with peroxidase. Sera from all three tomato allergic patients tested showed a strong IgE-binding to proteins from fruits of control plants (Figures $6 \mathrm{~A}-\mathrm{C}$ ). This binding was abolished (Figure 6A) or strongly reduced (Figures 6B,C) in extracts from transgenic tomato fruits, indicating that $\beta 1,2$-xylose epitopes are constitutive determinants for IgE-binding.

Since complex $N$-glycans carrying $\alpha 1,3$-fucose, but lacking $\beta 1,2$-xylose, are naturally found in some invertebrate glycoproteins such as hymenoptera venoms (Wilson and Altmann, 1998; Altmann, 2007), we decided to investigate the IgE-binding pattern of XylT_RNAi tomato lines with serum IgE antibodies obtained

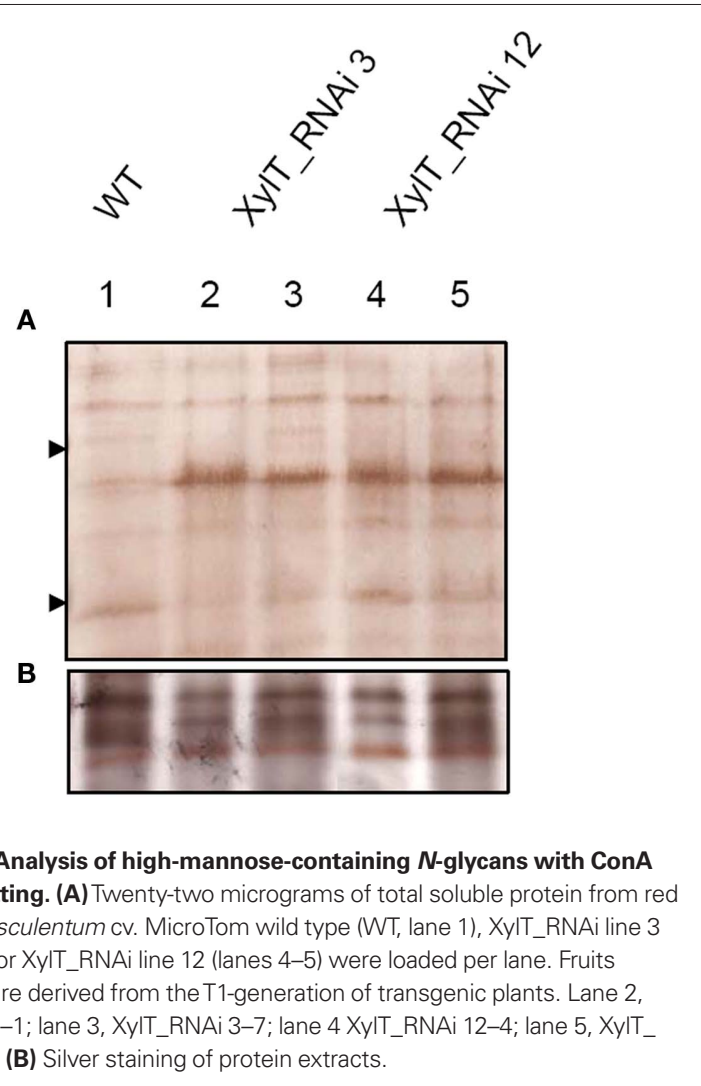




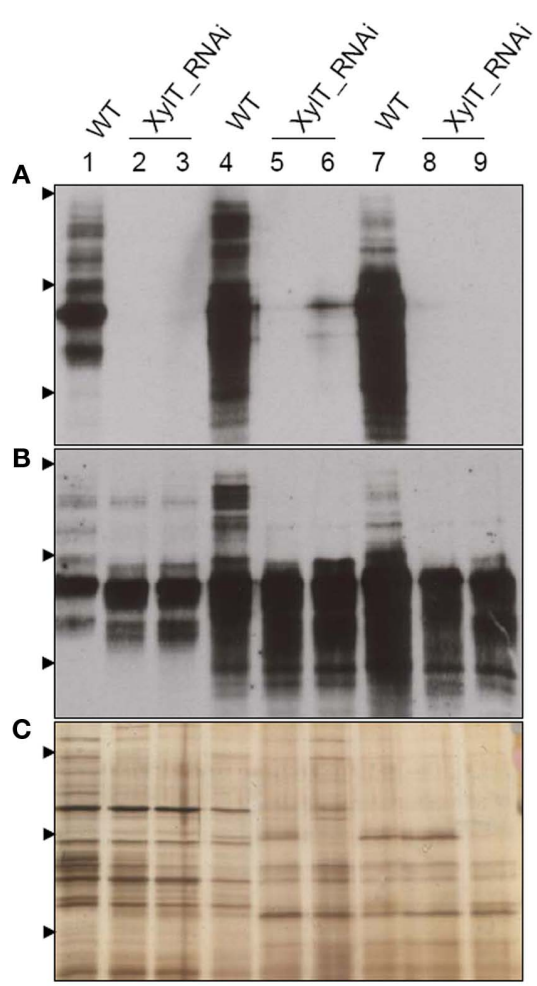

FIGURE 4 | Detection of fucose-containing $\mathbf{N}$-glycans in protein extracts from transgenic XyIT_RNAi and wild type tomato fruits. (A) Immunoblot using anti-xylose IgG antibodies; (B) Immunoblots using anti-fucose IgG antibodies; (C) Silver staining of SDS-PAGE. Protein extracts from green (lanes 1-3), orange (lanes 4-6), and red (lanes 7-9) tomato fruits were separated by SDS-PAGE and probed for xylose- or fucose-containing epitopes. Lanes 1, 4, and 7, protein extracts from wild type controls; lanes 2, 5, and 8, protein extracts from the T2 generation of line XyIT_RNAi 3-16-10; lanes 3, 6, and 9, protein extracts from the T2 generation of line XyIT_RNAi 12-15-1. Arrow heads indicate protein standards of 95,55 , and $36 \mathrm{kDa}$, respectively. from hymenoptera allergic patients. Fruit extracts from WT and XylT_RNAi lines were subjected to IgE immunoblot analysis using two representative sera from bee and yellow jacket venom allergic patients (Table 1; V 008, V 011). Serum from the bee/yellow jacket venom allergic patient $\mathrm{V} 008$ showed a strong binding to WT tomato fruits (Figure 7A, lane 1) and the XylT_RNAi extracts (Figure 7A, lane 2, XylT_RNAi 3-16; lane 3, XylT_RNAi 12-4). IgE antibodies of the bee/yellow jacket venom allergic patient $\mathrm{V} 011$ demonstrated in the IgE immunoblotting analysis clear reaction toward WT tomato extracts (Figure 7B, lane 1), whereas the IgEbinding to proteins of transgenic XylT_RNAi line 3-16 (Figure 7B, lane 2) and XylT_RNAi line 12-4 (Figure 7B, lane 3) was slightly reduced.

To release the carbohydrate moieties, protein extracts from WT fruits were treated with peptide- $N$-glycosidase (PNGase) A, which is able to remove the complex fucose-containing glycans of plant glycoproteins, in contrast to PNGase F (Tretter et al., 1991). After incubation with PNGase A for $36 \mathrm{~h}$, the serum of patient $\mathrm{V}$ 008 exhibited a decrease in IgE-binding to deglycosylated protein extracts, compared with control extract (Figure 7D). The additional band at about $62 \mathrm{kDa}$ represents most likely the PNGase A itself (Figure 7D, lane 2). When using the serum of bee/yellow jacket venom allergic patient $\mathrm{V}$ 011, most of the glycoprotein previously detected had lost its IgE-binding capacity after deglycosylation (Figure 7E).

Taken together, the IgE-binding to the $55 \mathrm{kDa}$-allergen in tomato is due to a xylose-containing epitope recognized by selective tomato allergic individuals, independently from a fucose-containing epitope also recognized by venom allergic individuals.

\section{REDUCED ALLERGENIC POTENCY OF XYIT RNAi TOMATO FRUITS IN VIVO DETERMINED BY SKIN PRICK TEST}

Fruits from XylT_RNAi lines and untransformed controls were used for a prick-to-prick test in three selected tomato allergic patients with known IgE-binding to the $52 \mathrm{kDa}$-component.

\section{$N$-glycosylation analysis}

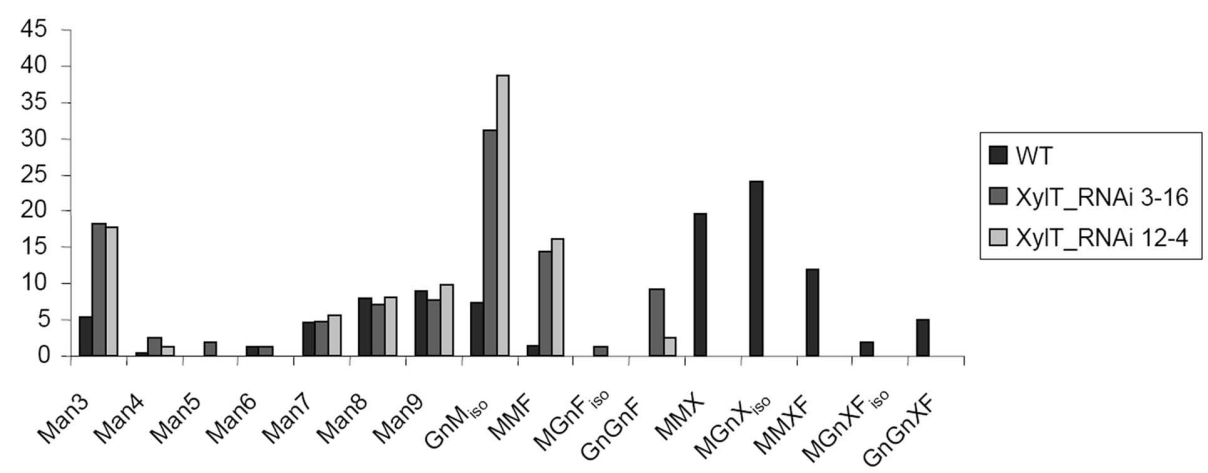

FIGURE 5 | $\mathbf{N}$-glycosylation analysis of tomato proteins by mass spectrometry. The area percentages were calculated from the peak areas within the mass spectra. Absolute SDs are typically in the range of 1-3\% with larger values for larger peaks and vice versa. Glycans carrying a xylose residue

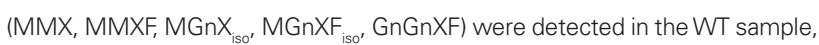
but not in XylT-RNAi samples. These contained increased amounts of the non-immunogenic $\mathrm{N}$-glycans such as Man3 and $\mathrm{MGn}_{\text {iso }} . \mathrm{N}$-glycans are annotated according to ProGlycan nomenclature (http://www.proglycan.com/). 


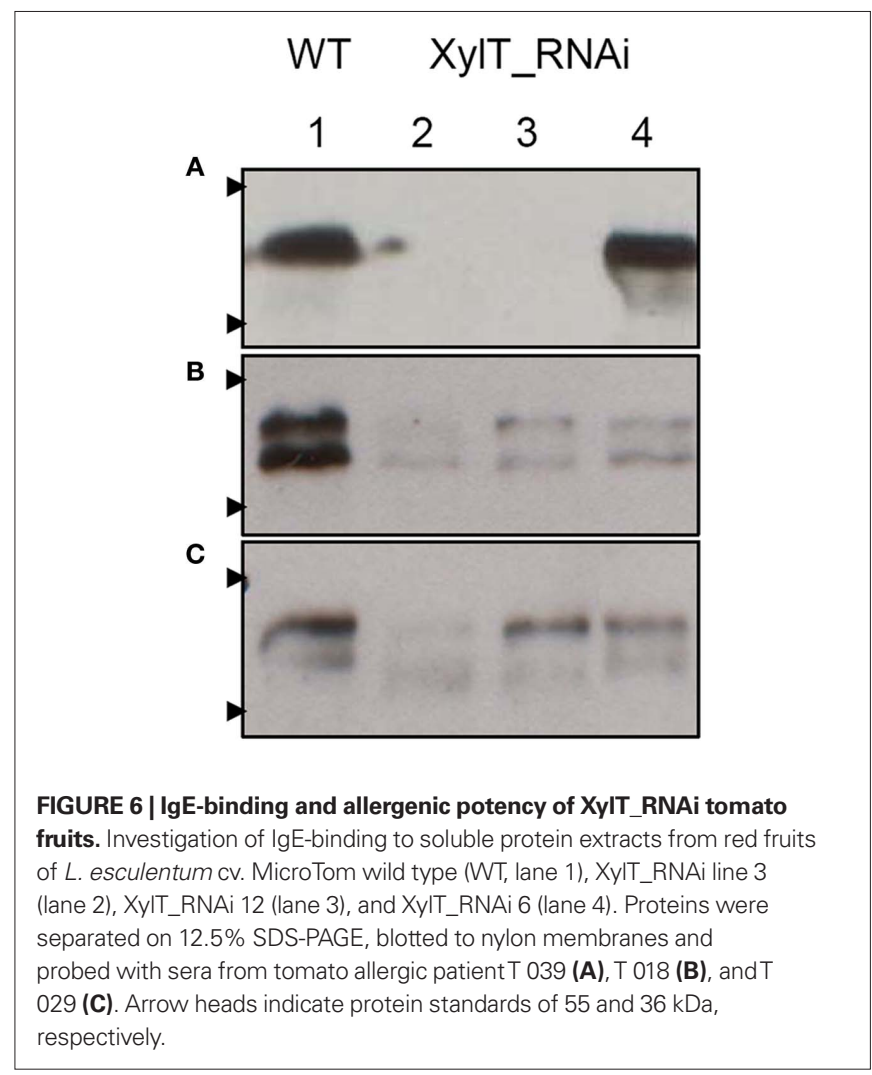

The wheal-and-flare reactions elicited by XylT_RNAi transgenic tomato fruits differed in the individual patients dependent on their co-sensitization to additional tomato proteins (Table 2). In mono-sensitized patient T 039 with exclusive IgE-binding to the $52 \mathrm{kDa}$-allergen of the tomato, depending on the cultivar $(\mathrm{Cv})$ a reduction of the mean wheal diameter of 4.3 (line XylT_RNAi 12-12) to $82.6 \%$ (lines XylT_RNAi 3-16 and line XylT_RNAi 12-3) was found in SPT with XylT_RNAi tomato fruits compared to the untransformed WT control (Table 2; patient T 039). A reduction of the mean wheal diameter was also observed in two other patients sensitized to the $52 \mathrm{kDa}$-allergen in SPT with the XylT-reduced tomato fruits, despite these patients were not mono-sensitized and the reduction of the IgE-mediated reactivity in the SPT was influenced by IgE-binding to non-silenced further allergens. In patient T 029 a reduction of 0 (line XylT_RNAi 12-3) to $100 \%$ (line XylT 3-1) could be noticed (Table 2, patient T 029). Patient $\mathrm{T} 018$ exhibited a reduction of mean wheal diameter of 18.2 (line XylT_RNAi 3-1) to 100\% (line XylT_RNAi 3-16; Table 2, patient T 018).

\section{SERA FROM LYC e 2-SENSITIZED PATIENTS SHOW A STRONGLY REDUCED IgE-BINDING TO PROTEINS FROM XYIT_RNAi TOMATO FRUITS} Examination of the immunoblots revealed one major immunoreactive protein migrating at a molecular weight of approximately $52 \mathrm{kDa}$, reminiscent of Lyc e 2, a major allergen of tomato fruits. Lyc e 2 is a glycoprotein with $\beta$-fructofuranosidase (E. C. 3.2.1.26) or soluble acid invertase activity. To test, whether

Table 1 | Characterization of patients (history, allergic symptoms, specific IgE (CAP FEIA analysis).

\begin{tabular}{|c|c|c|c|c|c|c|c|c|c|}
\hline ID & Age & Gender & Diagnosis/clinical symptoms & $\begin{array}{l}\text { CAP tomato } \\
\text { fruit }\end{array}$ & $\begin{array}{l}\text { CAP bee } \\
\text { venom }\end{array}$ & $\begin{array}{l}\text { CAP yellow } \\
\text { jacket } \\
\text { venom }\end{array}$ & $\begin{array}{l}\text { CAP } \\
\text { rapeseed }\end{array}$ & $\begin{array}{l}\text { CAP } \\
\text { bromelin }\end{array}$ & $\begin{array}{l}\text { CAP } \\
\text { horseradish } \\
\text { peroxidase }\end{array}$ \\
\hline Т 018 & 49 & $\mathrm{~F}$ & $\begin{array}{l}\text { OAS and contact urticaria } \\
\text { (tomato fuit), seasonal } \\
\text { rhinoconjunctivitis (birch pollen) }\end{array}$ & $\begin{array}{l}0.61 \mathrm{kU} / \mathrm{l} \\
\text { (class 1) }\end{array}$ & $\begin{array}{l}0.80 \text { kU/l } \\
\text { (class 2) }\end{array}$ & $\begin{array}{l}0.82 \text { kU/l } \\
\text { (class 2) }\end{array}$ & $\begin{array}{l}0.64 \mathrm{kU} / \mathrm{l} \\
\text { (class 1) }\end{array}$ & $\begin{array}{l}0.50 \mathrm{kU} / \mathrm{l} \\
\text { (class 1) }\end{array}$ & $\begin{array}{l}0.40 \mathrm{kU} / \mathrm{l} \\
\text { (class 1) }\end{array}$ \\
\hline Т 029 & 51 & $\mathrm{~F}$ & $\begin{array}{l}\text { OAS (tomato fruit and carrot, } \\
\text { seasonal rhinoconjunctivitis } \\
\text { (birch pollen) }\end{array}$ & $\begin{array}{l}11.9 \mathrm{kU} / \mathrm{l} \\
\text { (class 3) }\end{array}$ & $\begin{array}{l}44.2 \mathrm{kU} / \mathrm{l} \\
\text { (class 4) }\end{array}$ & $\begin{array}{l}3.04 \mathrm{kU} / \mathrm{l} \\
\text { (class 2) }\end{array}$ & $\begin{array}{l}27.2 \mathrm{kU} / \mathrm{l} \\
\text { (class 4) }\end{array}$ & $\begin{array}{l}6.00 \mathrm{kU/l} \\
\text { (class 3) }\end{array}$ & $\begin{array}{l}6.25 \text { kU/l } \\
\text { (class 3) }\end{array}$ \\
\hline Т039 & 54 & M & $\begin{array}{l}\text { OAS, Quickes' edema and } \\
\text { dypnoea (tomato fruit), seasonal } \\
\text { rhinoconjunctivitis (birch pollen) }\end{array}$ & $\begin{array}{l}0.14 \mathrm{kU} / \mathrm{l} \\
\text { (class 0) }\end{array}$ & $\begin{array}{l}0.21 \mathrm{kU} / \mathrm{l} \\
\text { (class 0) }\end{array}$ & $\begin{array}{l}0.05 \text { kU/l } \\
\text { (class 1) }\end{array}$ & $\begin{array}{l}0.68 \mathrm{kU} / \mathrm{l} \\
\text { (class 1) }\end{array}$ & $\begin{array}{l}0.05 \mathrm{kU} / \mathrm{l} \\
\text { (class 0) }\end{array}$ & $\begin{array}{l}0.02 \text { kU/l } \\
\text { (class 0) }\end{array}$ \\
\hline V 001 & 22 & $\mathrm{~F}$ & $\begin{array}{l}\text { Type I allergy to yellow jacket } \\
\text { venom (grade I according to } \\
\text { Mueller), ongoing specific } \\
\text { immunotherapy (yellow jacket } \\
\text { venom) }\end{array}$ & $\begin{array}{l}0.58 \mathrm{kU} / \mathrm{l} \\
\text { (class 1) }\end{array}$ & $\begin{array}{l}0.73 \text { kU/l } \\
\text { (class 2) }\end{array}$ & $\begin{array}{l}0.97 \text { kU/l } \\
\text { (class 2) }\end{array}$ & $\begin{array}{l}0.80 \mathrm{kU} / \mathrm{l} \\
\text { (class 2) }\end{array}$ & $\begin{array}{l}0.57 \mathrm{kU} / \mathrm{l} \\
\text { (class 1) }\end{array}$ & $\begin{array}{l}0.67 \text { kU/l } \\
\text { (class 1) }\end{array}$ \\
\hline V 002 & 32 & $\mathrm{~F}$ & $\begin{array}{l}\text { Type I allergy to yellow jacket } \\
\text { venom (grade II according to } \\
\text { Mueller), ongoing specific } \\
\text { immunotherapy (yellow jacket } \\
\text { venom) }\end{array}$ & $\begin{array}{l}0.15 \mathrm{kU} / \mathrm{l} \\
\text { (class 0) }\end{array}$ & $\begin{array}{l}0.24 \text { kU/l } \\
\text { (class 0) }\end{array}$ & $\begin{array}{l}27.4 \mathrm{kU} / \mathrm{l} \\
\text { (class 4) }\end{array}$ & $\begin{array}{l}0.17 \mathrm{kU} / \mathrm{l} \\
\text { (class 0) }\end{array}$ & $\begin{array}{l}0.15 \mathrm{kU} / \mathrm{l} \\
\text { (class 0) }\end{array}$ & $\begin{array}{l}0.10 \text { kU/I } \\
\text { (class 0) }\end{array}$ \\
\hline
\end{tabular}


Table 1 | Continued

\begin{tabular}{|c|c|c|c|c|c|c|c|c|c|}
\hline V 004 & 24 & $M$ & $\begin{array}{l}\text { Type I allergy to bee and yellow } \\
\text { jacket venom (grade III } \\
\text { according to Mueller) }\end{array}$ & $\begin{array}{l}0.33 \mathrm{kU} / \mathrm{l} \\
\text { (class } 0 \text { ) }\end{array}$ & $\begin{array}{l}26.6 \mathrm{kU} / \mathrm{l} \\
\text { (class 4) }\end{array}$ & $\begin{array}{l}10.1 \mathrm{kU} / \mathrm{l} \\
\text { (class 3) }\end{array}$ & $\begin{array}{l}0.52 \mathrm{kU} / \mathrm{l} \\
\text { (class 1) }\end{array}$ & $\begin{array}{l}0.57 \mathrm{kU} / \mathrm{l} \\
\text { (class 1) }\end{array}$ & $\begin{array}{l}0.71 \mathrm{kU} / \mathrm{l} \\
\text { (class 2) }\end{array}$ \\
\hline V 005 & 45 & $M$ & $\begin{array}{l}\text { Type I allergy to yellow jacket } \\
\text { venom (grade II according to } \\
\text { Mueller) }\end{array}$ & $\begin{array}{l}0.11 \mathrm{kU} / \mathrm{l} \\
\text { (class 0) }\end{array}$ & $\begin{array}{l}0.18 \mathrm{kU} / \mathrm{l} \\
\text { (class 0) }\end{array}$ & $\begin{array}{l}1.12 \mathrm{kU} / \mathrm{l} \\
\text { (class 2) }\end{array}$ & $\begin{array}{l}0.11 \mathrm{kU} / \mathrm{l} \\
\text { (class 0) }\end{array}$ & $\begin{array}{l}0.10 \mathrm{kU} / \mathrm{l} \\
\text { (class 0) }\end{array}$ & $\begin{array}{l}0.09 \mathrm{kU} / \mathrm{l} \\
\text { (class 0) }\end{array}$ \\
\hline V 008 & 50 & $M$ & $\begin{array}{l}\text { Type I allergy to bee venom } \\
\text { (grade II according to Mueller), } \\
\text { ongoing specific } \\
\text { immunotherapy (bee venom) }\end{array}$ & $\begin{array}{l}0.53 \mathrm{kU} / \mathrm{l} \\
\text { (class 1) }\end{array}$ & $\begin{array}{l}6.39 \mathrm{kU} / \mathrm{l} \\
\text { (class 3) }\end{array}$ & $\begin{array}{l}1.28 \mathrm{kU} / \mathrm{l} \\
\text { (class 2) }\end{array}$ & $\begin{array}{l}0.53 \mathrm{kU} / \mathrm{l} \\
\text { (class 1) }\end{array}$ & $\begin{array}{l}0.47 \mathrm{kU} / \mathrm{l} \\
\text { (class 1) }\end{array}$ & $\begin{array}{l}0.5 \mathrm{kU} / \mathrm{l} \\
\text { (class 1) }\end{array}$ \\
\hline V 010 & 61 & $M$ & $\begin{array}{l}\text { Type I allergy to yellow jacket } \\
\text { venom (grade II according to } \\
\text { Mueller), ongoing specific } \\
\text { immunotherapy (yellow jacket } \\
\text { venom) }\end{array}$ & $\begin{array}{l}5.01 \mathrm{kU} / \mathrm{l} \\
\text { (class 3) }\end{array}$ & $\begin{array}{l}4.30 \mathrm{kU} / \mathrm{l} \\
\text { (class 3) }\end{array}$ & $\begin{array}{l}29.5 \mathrm{kU} / \mathrm{l} \\
\text { (class 4) }\end{array}$ & $\begin{array}{l}5.37 \mathrm{kU} / \mathrm{l} \\
\text { (class 3) }\end{array}$ & $\begin{array}{l}4.00 \mathrm{kU} / \mathrm{l} \\
\text { (class } 3 \text { ) }\end{array}$ & $\begin{array}{l}5.01 \mathrm{kU} / \mathrm{l} \\
\text { (class 3) }\end{array}$ \\
\hline V 013 & 20 & $M$ & $\begin{array}{l}\text { Type I allergy to bee venom } \\
\text { (grade II according to Mueller), } \\
\text { ongoing specific } \\
\text { immunotherapy (bee venom) }\end{array}$ & $\begin{array}{l}2.59 \mathrm{kU} / \mathrm{l} \\
\text { (class 2) }\end{array}$ & $\begin{array}{l}10.6 \mathrm{kU} / \mathrm{l} \\
\text { (class 3) }\end{array}$ & $\begin{array}{l}0.07 \mathrm{kU} / \mathrm{l} \\
\text { (class 0) }\end{array}$ & $\begin{array}{l}\text { 1. } 23 \mathrm{kU} / \mathrm{l} \\
\text { (class 2) }\end{array}$ & $\begin{array}{l}0.22 \mathrm{kU} / \mathrm{l} \\
\text { (class 0) }\end{array}$ & $\begin{array}{l}0.31 \mathrm{kU} / \mathrm{l} \\
\text { (class 0) }\end{array}$ \\
\hline V 014 & 49 & $M$ & $\begin{array}{l}\text { Type I allergy to bee venom } \\
\text { (grade } 0 \text { according to Mueller) }\end{array}$ & $\begin{array}{l}0.02 \mathrm{kU} / \mathrm{l} \\
\text { (class } 0 \text { ) }\end{array}$ & $\begin{array}{l}10.3 \mathrm{kU} / \mathrm{l} \\
\text { (class } 3 \text { ) }\end{array}$ & $\begin{array}{l}0.03 \mathrm{kU} / \mathrm{l} \\
\text { (class 0) }\end{array}$ & $\begin{array}{l}0.02 \mathrm{kU} / \mathrm{l} \\
\text { (class 0) }\end{array}$ & $\begin{array}{l}0.02 \mathrm{kU} / \mathrm{l} \\
\text { (class 0) }\end{array}$ & $\begin{array}{l}0.01 \mathrm{kU} / \mathrm{l} \\
\text { (class 0) }\end{array}$ \\
\hline
\end{tabular}

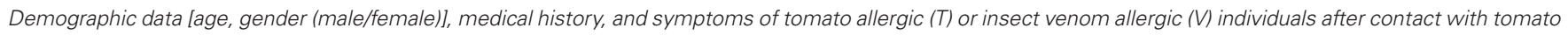

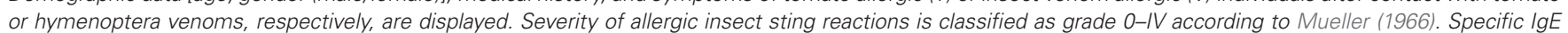

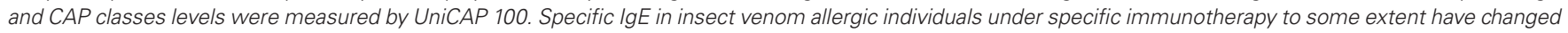

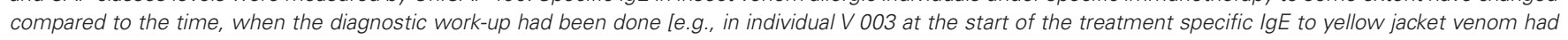
been $1.04 \mathrm{kU} / \mathrm{l}$ (CAP class 2)].

the $\beta 1,2$-xylose residues would be required for IgE-binding, sera of two Lyc e 2-sensitized patients (Westphal et al., 2003) were used for IgE immunoblot analysis. In control extracts IgE-binding to high-molecular-weight bands could be found for both Lyc e 2-sensitized patients. In contrast, no IgE-binding could be detected with the protein extracts from XylT_RNAi tomato fruits (Figures $\mathbf{8 A}, \mathbf{B}$ ). The loading control is shown in Figure 8C. 
These results suggest that $\beta 1,2$-xylose is a major determinant of the Lyc e 2 IgE-specific epitope.

\section{SOLUBLE ACID INVERTASE ACTIVITY IS UNALTERED IN TRANSGENIC XyIT_RNAi PLANTS}

To rule out that the reduced binding to Lyc e 2 in extracts from XylT_RNAi lines was due to a reduced accumulation of soluble acid invertase, enzyme activity was measured in leaves and fruits of transgenic and control tomato plants. As shown in Figure 9, soluble acid invertase activity in protein extracts from transgenic plants was indistinguishable from the activity determined in control extracts. Thus down-regulation of the XylT does not negatively influence the accumulation and activity of Lyc e 2, as determined by invertase measurement.

\section{DISCUSSION}

\section{REDUCTION OF FOOD ALLERGENS BY MEANS OF RNA INTERFERENCE}

Food allergies represent an increasing health concern impairing quality of life in affected adults and children. As until now no specific immunotherapy for food allergies is available, avoidance of the respective food is the current primary treatment option. Up to now different breeding activities have been undertaken to select for lowallergenic Cvs (Bolhaar et al., 2005; Zuidmeer et al., 2006). However, so far no commercial variety has been obtained. The difficulties in breeding for low-allergenic varieties may in part be due to environmental factors regulating allergen accumulation during growth and storage which renders classical selection procedures difficult (Scheurer and Sonnewald, 2009). Some approaches for the suppres- sion of known allergens in food by means of genetic engineering have been followed in the last years for soybean, rice, peanut, cherry, apple, and tomato (reviewed in Scheurer and Sonnewald, 2009). Most of these approaches used the so-called RNAi to reduce expression of allergenic proteins. RNAi has been shown to be a selective and robust tool, but it may also have limitations. Some biotic and abiotic factors were found effecting the stability and efficacy of RNAi under varying environmental conditions (Szittya et al., 2003). Many plant viruses

\section{Table 2 | Skin prick tests with XylT-silenced tomato fruits.}

\begin{tabular}{llll}
\hline Probe & PatientT 039 & PatientT 018 & PatientT 029 \\
\hline Histamine & MWD (mm) & MWD (mm) & MWD (mm) \\
Sodium chloride & 5.25 & 6 & 6.5 \\
XylT_RNAi 3-1 & 3 & 0 & 0 \\
XylT_RNAi 3-7 & 2 & 3.6 & 0 \\
XylT_RNAi 3-10 & 4.5 & 2.75 & 8 \\
XylT_RNAi 3-16 & 1 & 3 & 5.5 \\
XylT_RNAi 12-3 & 1 & 0 & 4.5 \\
XylT_RNAi 12-4 & 2 & 2.5 & 9.85 \\
XylT_RNAi 12-12 & 5.5 & 5 & 6 \\
XylT_RNAi 12-15 & 5 & 3.25 & 8 \\
Wild type & 5.75 & 3.5 & 4.5 \\
\hline
\end{tabular}

Skin-prick-test of tomato allergic patients using fruits of WT, XylT-silenced (XYIT_RNAi) lines 3, and 12. The mean wheal diameters (MWD) are indicated in millimeters. Histamine dihydrochloride was used as positive control.

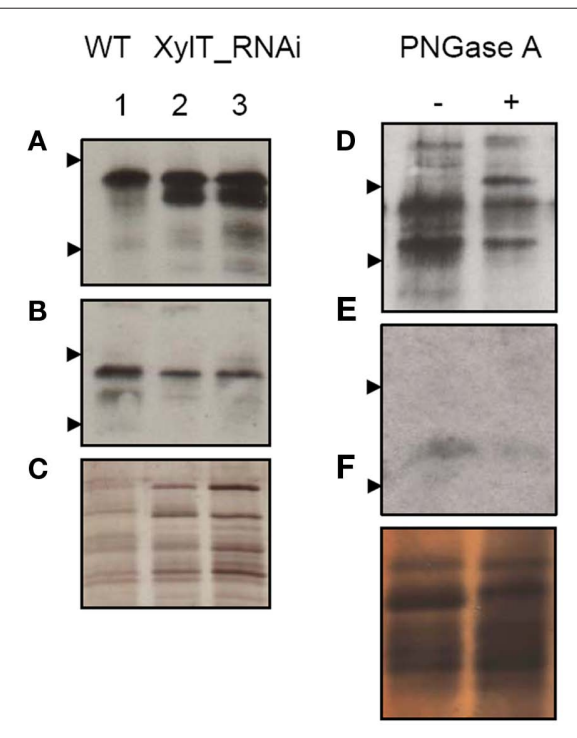

FIGURE 7 | Immunoblot analysis of hymenoptera allergic patients. Immunoblots of tomato red fruits extracts were incubated with selected sera from hymenoptera allergic patients (see Table 1) V 008 (A) and V 011 (B) and developed for detection of human IgE. (C) Protein staining with silver as loading control. Lane 1, WT; lane 2, XyIT_RNAi 3-16; lane 3, XyIT_RNAi 12-4. Blotted WT extracts showed reduced IgE-binding after PNGase A treatment. (D) $\vee 008$, (E) $\vee 011$, (F) Silver staining of proteins as loading control. Arrow heads show protein standards of 55 and $36 \mathrm{kDa}$.

\section{WT XylT_RNAi 3 WT XylT_RNAi 12 \\ $\begin{array}{llllllllll}1 & 2 & 3 & 4 & 5 & 6 & 7 & 8 & 9 & 10\end{array}$}

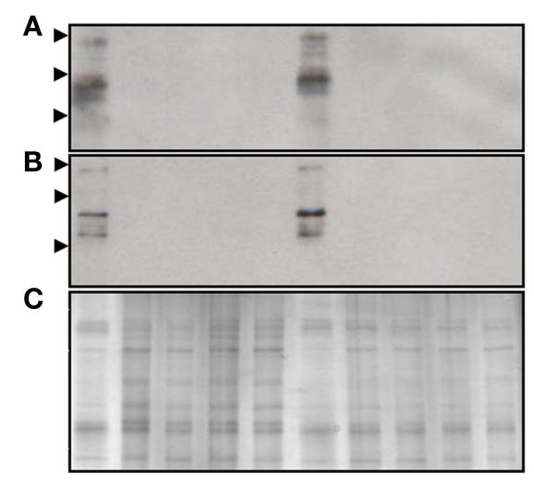

FIGURE 8 | Immunoblot of XyIT_RNAi tomato fruits using IgE from Lyc e 2-sensitized patients. IgE-binding to soluble protein extracts from red tomato fruits harvested from L. esculentum cv. MicroTom wild type (WT, lanes 1 and 6), XyIT_RNAi line 3 (lanes 2-5), XYIT_RNAi 12 (lanes 7-10). (A) IgE-binding using serum from patient 7241-7, (B) IgE-binding using serum from patient 8695-24. Fruits analyzed were derived from the T1-generation of transgenic plants. Lane 2, XylT_RNAi 3-1; lane 3, XyIT_RNAi 3-7; lane 4, XyIT_RNAi 3-10; lane 5, XylT_RNAi 3-16; lane 7,WT; lane 8, XyIT_RNAi 12-3; lane 9, XyIT_RNAi 12-4; lane 10, XYIT_RNAi 12-12. (C) SDS-PAGE and silver staining of protein extracts from red fruits. Arrow heads indicate protein standards of 95, 55, and $36 \mathrm{kDa}$, respectively. 


\section{Soluble acid invertase activity}

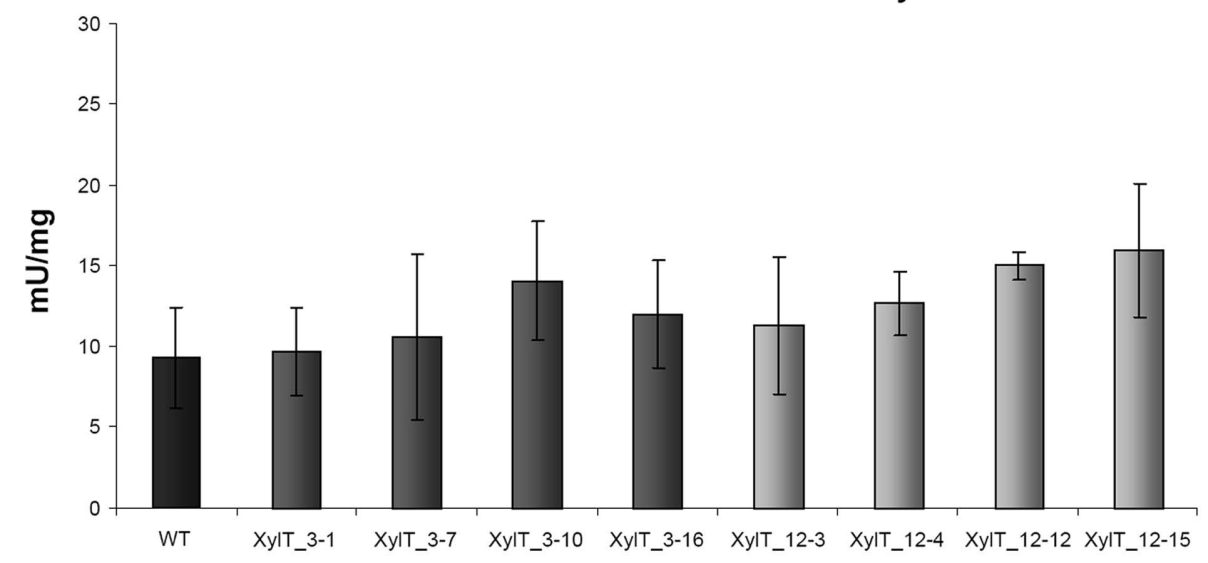

FIGURE 9 | Invertase enzyme activity measurements. Soluble invertase activity in protein extracts from leaves of L. esculentum cV. MicroTom wild type (WT) and independent T1-plants of transgenic XyIT_RNAi line 3 and 12.

encode suppressors of silencing (Roth et al., 2004) which could counteract the application of the RNAi technology under field conditions. This could potentially be overcome by applying artificial microRNAs to suppress expression of allergenic proteins. Another limitation of gene silencing resides in the observation that several allergens represent essential cellular functions (Le et al., 2006). To overcome this problem simultaneous over-expression of hypo-allergenic variants of the respective allergen would be required. In a recent study, Le et al. (2010) could demonstrate that the growth penalty of Lyc e 1 silencing could be overcome by co-expression of yeast profilin. One further limitation in designing hypo-allergenic food is that most allergic patients are not only sensitized to one single allergen, but to multiple proteins from the respective food. Therefore, multi-target silencing will be the next challenge for future experiments.

\section{MODULATION OF $\boldsymbol{N}$-GLYCOSYLATION IN PLANTS}

In all eukaryotic cells glycosylation of asparagine residues ( $N$-glycosylation) is a highly conserved co-translational modification of secreted proteins. The process is separated into coreglycosylation and glycan maturation. The core-glycosylation takes place in the ER where pre-assembled core oligosaccharides $\left(\mathrm{Glc}_{3} \mathrm{Man}_{9} \mathrm{GlCNac}_{2}\right.$ ) are transferred to asparagine residues of the Asn/X-Ser/Thr motives in nascent polypeptides. The glycan maturation in the Golgi apparatus has been shown to be crucial for the formation of complex $N$-glycans. In the last years several plant mutants lacking complex $N$-glycans were published. The first one was the cgll mutant in 1993 (von Schaewen et al., 1993). In the meantime, several mutants and transgenic plants which were devoid of potentially immunogenic complex $N$-glycans have been generated and are used for the production of pharmaceutical proteins in the respective plants (Lerouge et al., 2000; Koprivova et al., 2004; Cox et al., 2006; Strasser et al., 2008, 2009). The plant specific sugar residues, $\beta 1,2$-xylose and $\alpha 1,3$-fucose are not present in mammals and therefore constitute epitopes for carbohydrate reactive antibodies (Tretter et al., 1993; Wilson and Altmann, 1998; van Ree et al., 2000; Bencurova et al., 2004). An overall prevalence of specific anti-glycan IgE of $23 \%$ in human sera has been described with an increase up to $71 \%$ (in individu- als with multiple pollen sensitivity) according to the examined subset. These CCD dependent IgE antibodies are often accompanied by IgG, but the clinical relevance is still under debate. A clinical insignificance of CCDs has been proposed in some studies (van der Veen et al., 1997; Mari, 2002). In a recent study Kaulfürst-Soboll et al. (2011) used transgenic tomato plants with an overall reduction in protein $N$-glycosylation and confirmed the low clinical significance of CCDs.

In our study we addressed the question whether down-regulation of $\beta 1,2$-xylose-containing epitopes would reduce the allergenic potential of tomato fruits in respective tomato allergic individuals sensitized to a $52 \mathrm{kDa}$-allergen.

To this end RNAi was used to down-regulate the expression of XylT in tomato plants. Immunoblot analysis revealed that accumulation of glycoproteins carrying $\beta 1,2$-xylose were strongly reduced in transgenic XylT_RNAi lines in comparison to control extracts (Figure 2A). Reduced accumulation of XylT mRNA was confirmed for XylT_RNAi lines 3, 12, and 9 by qPCR (Figure 1B). Strongly reduced xylose content of $N$-glycans resulted in enhanced ConA binding and a slight reduction in fucose content of glycoproteins from XylT_RNAi plants, as determined by immunoblotting (Figures 3 and $4 \mathrm{~B}$ ). The changes in $N$-glycosylation pattern in XylT_RNAi lines were monitored in $N$-glycan analysis by MS. The $N$-glycan profile of the WT sample demonstrated that the vast majority of the $N$-glycan species were xylosylated and fucosylated. In contrast to the WT $N$-glycosylation pattern, the mass spectrum of the XylT_RNAi plants revealed a complete loss of $\beta 1,2$-xylose and a reduction of fucose carrying $N$-glycans (Figure 5). This finding is in agreement with results obtained by analyzing XylT knockout lines in Arabidopsis, which showed an increase in highmannose and a decrease in fucose-containing $N$-glycans (Strasser et al., 2004). Using sera of tomato allergic patients, a decreased residual IgE-binding to proteins from XylT_RNAi plants could be detected for two patients, whereas one patient revealed no IgE reactivity toward the XylT_RNAi tomato lines 3 and 12 (Figure 6). In contrast, IgE-binding of sera from insect allergic patients evidently raised against a fucose-containing epitope was maintained in xylose reduced XylT_RNAi tomato lines (Figure 7). 
When patients T 029 and T 018 were challenged in SPT depending on the $\mathrm{Cv}$ and their co-sensitizations to additional tomato allergens they showed only a scarce reduction of the skin reaction to XylT_RNAi fruits (Table 1, patient T 029 and T 018). Patient T 039 with a clear history of clinically relevant tomato allergy was shown to be mono-sensitized to the $52 \mathrm{kDa}$ tomato protein, which we could identify as Lyc e 2. In the SPT a visible reduction in mean wheal diameters with five out of eight XylT_RNAi Cvs could be observed.

Lyc 2 has been identified as one of the major allergens in tomato fruits. Kondo et al. (2001) have reported that sera of most patients with an oral allergy syndrome to tomato positively responded to Lyc e 2 ( 9 of 11 patients). In our collective of tomato allergic patients, only $4.4 \%$ of patients ( 3 of 68 ) were sensitized against this allergen (only one of them monosensitized to this allergen).

Lyc e 2 is known to be a vacuolar enzyme with soluble acid invertase ( $\beta$-fructofuranosidase) activity (Leigh et al., 1979). The enzyme catalyzes the hydrolysis of sucrose into glucose and fructose. The role of soluble acid invertase in plants is complex and may change in response to developmental and environmental signals. Soluble acid invertases are considered to be important in growth,

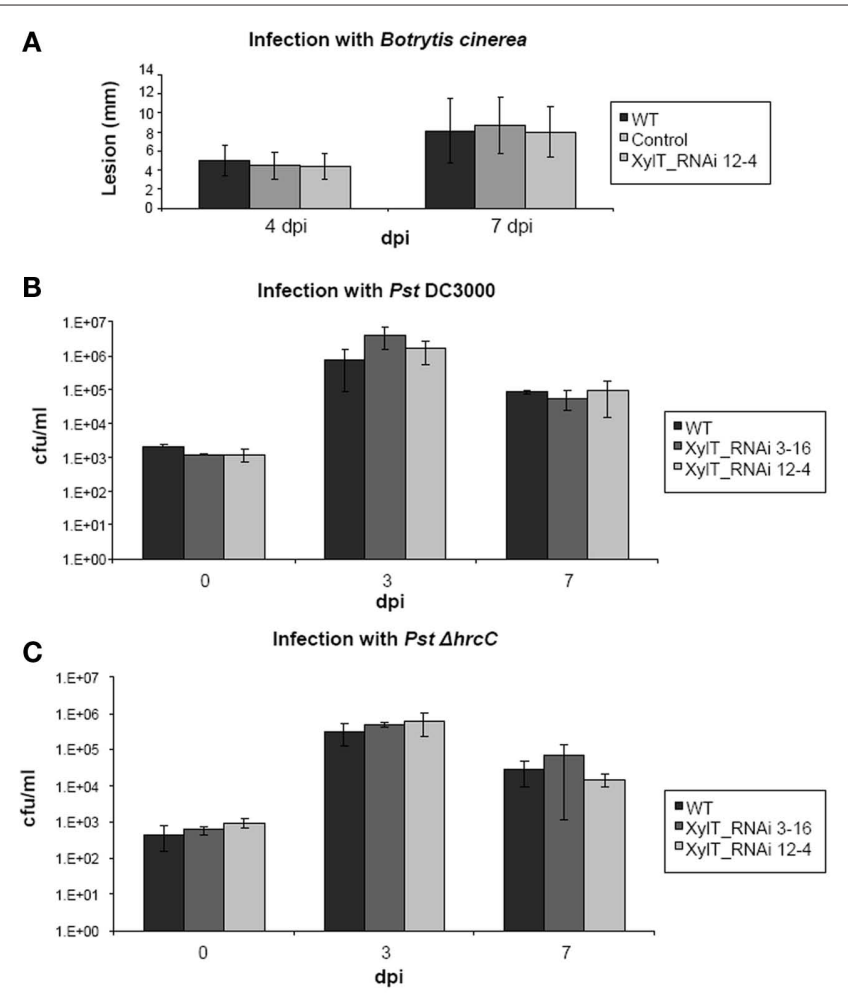

FIGURE 10 | Fungal and bacterial growth in planta. (A) Wild type tomato (MicroTom), XylT_RNAi 12-4 as well as transformed control plants were grown for 6 weeks. After this time period detached 5 th and 6 th leaves were placed on $0.5 \%$ water agar and drop-inoculated $(4 \times 20 \mu \mathrm{l}$ drops per leaf) with conidia of Botrytis cinerea 522. The inoculation solution contained $5 \times 10^{4}$ conidia/ml of $1 / 2$ potato dextrose broth. After inoculation, lesion size was measured 4 and 7 days after inoculation. (B) Bacterial growth in planta after infection of MicroTom tomato leaves with Pseudomonas DC3000 and Pseudomonas DC3000 $\Delta$ hrcC Strain TLR1 (C) was monitored over a 13-day period. Bacteria were infiltrated with $1 \times 10^{5} \mathrm{cfu} / \mathrm{ml}$, and their growth was determined 3 and 7 days after inoculation. Values represent means of two samples taken from three infected leaves of three different plants. Error bars indicate SD. The experiment was repeated twice with similar results. providing tissues with hexoses as a source of energy, and carbon (Scholes et al., 1996). To see if the silencing of the XylT and the resulting modification of the $N$-glycosylation had a negative effect on the activity of soluble acid invertase, we measured invertase activity in WT and transgenic XylT_RNAi fruits (Figure 9). Neither had the silencing an effect on the expression of the soluble acid invertase, nor could an effect on the activity of the enzyme be observed when comparing WT and XylT_RNAi protein extracts.

Concerning growth and development, the transgenic XylT_RNAi lines exhibited no obvious phenotypic changes compared to WT controls under ambient growth conditions. This is in accordance with results obtained for other plants in which XylT and/or FucT were silenced, like Arabidopsis thaliana and Nicotiana benthamiana (Strasser et al., 2004, 2008). Nevertheless, we cannot exclude that down-regulation of XylT renders transgenic plants more susceptible to biotic and/or abiotic stress. It has been published that mutants defective in complex $N$-glycans showed enhanced salt sensitivity (Kang et al., 2008) and that $N$-glycosylation is required for pattern recognition to mediate plant immunity (Häweker et al., 2010). First experiments using the fungal pathogen Botrytis cinerea and different Pseudomonas syringae strains lead to the assumption that the plant immunity is not affected in this case (Figure 10), but further experiments with different biotic and abiotic stress factors are required.

\section{CONCLUSION}

In our study we could demonstrate that a xylose-containing epitope is the clinically relevant epitope for Lyc e 2-sensitized tomato allergic individuals. Furthermore, we could show that $\beta 1,2$-xylose modifications of $\mathrm{N}$-glycans modify specific IgE-binding in vitro and in vivo in individuals allergic to Lyc e 2. Thus our study challenges two widely hold hypotheses. First, that human IgE reacts essentially only to the core $\alpha 1,3$-fucose epitope (Bencurova et al., 2004). Second, that IgE against carbohydrate has no clinical relevance and does not result in strong skin test reactions (Mari, 2002; Mertens et al., 2010). Possibly, Lyc e 2 is the special case of an allergen where the sugar moiety together with the protein constitutes a clinically relevant epitope.

\section{MATERIALS AND METHODS CHARACTERIZATION OF PATIENTS' SERA}

Approval of the local ethics committee (faculty of medicine, University of Erlangen-Nuremberg, No. 3344) to this study and written informed consent of all participants was obtained.

For this study, three sera with specific IgE-binding to a $52 \mathrm{kDa}$ protein were used [i.e., $4.4 \%$ out of $n=68$ sera from tomato allergic patients $(\mathrm{T})$ with clinical symptoms upon ingestion of tomato fruits (see Table 1)]. Allergy diagnosis was based on a positive case history, positive specific IgE against tomato fruit in vitro and positive skin prick test results (consisting of a mean wheal diameter of more than $3 \mathrm{~mm}$ ). For control purposes concerning specific IgE-binding to cross-reactive carbohydrate determinants, 10 sera were obtained from symptomatic insect venom allergic patients (V; Table 1) without clinically manifest allergic reactions to tomato fruits despite elevated serum IgE to tomato extract in some of them.

\section{PLANT MATERIAL AND GROWTH CONDITIONS}

Tomato plants (L. esculentum cv. MicroTom) were grown in a Percival growth chamber (Percival Scientific, Boone, USA) under a $16 \mathrm{~h}$ light/ $8 \mathrm{~h}$ dark cycle on Murashige-Skoog medium containing 
$2 \%(\mathrm{w} / \mathrm{v})$ sucrose. After the initial characterization of in vitro-grown plants, tomato plants were transferred to a greenhouse. The plants were cultivated in soil with $16 \mathrm{~h}$ light followed by $8 \mathrm{~h}$ of darkness. The temperature regime followed the day/night cycle with $25 / 20^{\circ} \mathrm{C}$.

\section{PLASMID CONSTRUCTION}

To obtain the XylT-RNAi construct the Gateway technology (Invitrogen, Karlsruhe, Germany) was used.A $\beta 1,2$-xylosyltransferase (Accession Number BG130152) fragment of 475 bp was amplified from $L$. esculentum green fruit cDNA using the forward primer XylT_ RNAi 5' (5'-AATGTCCTCTTTGTTAGACG-3') and reverse primer XylT_RNAi 3' (5'-GTGGGTCTTGTAGAGAAAAG-3') which were designed on the basis of sequence homology to already annotated XylT sequences in the database. PCR conditions were as follows: $95^{\circ} \mathrm{C}$ for $5 \mathrm{~min} \mathrm{~N}$-acetyl-beta-glucosaminyl followed by 30 cycles of $95^{\circ} \mathrm{C}$ for $30 \mathrm{~s}, 55^{\circ} \mathrm{C}$ for $60 \mathrm{~s}$, and $72^{\circ} \mathrm{C}$ for $60 \mathrm{~s}$, and a final extension at $72^{\circ} \mathrm{C}$ for $10 \mathrm{~min}$. The PCR fragment was introduced into $\mathrm{pENTR} / \mathrm{D}-$ TOPO vector (Invitrogen) to create an entry clone containing the attL recombination sites. Subsequently, the lambda reconstruction (LR) recombination reaction was performed, according to the instructions of the manual, to transfer the fragment into the destination vector pK7GWIWG2 (II; Karimi et al., 2002) containing the attR attachment sites. Thereby the final construct, designated as pK7GWIWG2-XylT was generated, carrying the XylT fragment in sense and antisense orientation separated by an intron under control of the constitutive cauliflower mosaic virus 35S-promotor.

\section{PLANT TRANSFORMATION}

The pK7GWIWG2-XylT construct was transformed into A. tumefaciens CV58C1, carrying the hyper virulence attenuated tumorinducing helper plasmid pGV2260. Tomato cotyledon explants were transformed and regenerated as described by Ling et al. (1998).

\section{In planta growth of Botrytis cinerea and Pseudomonas syringae pv. tomato}

For fungal infection WT tomato (MicroTom), XylT_RNAi 12-4 as well as transformed control plants were grown in soil at $22 / 18^{\circ} \mathrm{C}$ day/ night cycle (16 h light; $53 \mathrm{mmol} / \mathrm{m} / \mathrm{s}$ photon flux density) at $60 \%$ rel. humidity in a growth chamber. After 6 weeks detached fifth and sixth leaves were placed on $0.5 \%$ water agar (Roth) and drop-inoculated $(4 \times 20 \mu \mathrm{l}$ drops per leaf) with conidia of Botrytis cinerea 522 (culture collection of the Institute of Phytopathology and Applied Zoology, Giessen, Germany). The inoculation solution contained $5 \times 10^{4}$ conidia/ml of $1 / 2$ potato dextrose broth (Duchefa). After inoculation, plates were kept at RT. Lesion size was measured 4 and 7 days after inoculation. To monitor the growth of Pseudomonas syringae pv. tomato DC3000 and Pseudomonas syringae pv. tomato DC3000 $\Delta h r c C$ Strain TLR1 in tomato plants, leaves were inoculated with a bacterial suspension of $1 \times 10^{5} \mathrm{cfu} / \mathrm{ml}$. Bacterial levels in planta were determined by homogenizing leaf disks in sterile water, plating appropriate dilutions on NYG agar plates containing rifampicin $(100 \mu \mathrm{g} / \mathrm{ml})$, and counting the number of bacterial colonies.

\section{RNA ISOLATION AND OPCR BASED OUANTIFICATION OF XYLT EXPRESSION IN TRANSGENIC PLANTS}

The quantification of XylT expression in different transgenic tomato plants was evaluated in the T1-generation of XylT-silenced plants based on Lyc e 1 transcript accumulation using RT-PCR.
To this end, total RNA was isolated from leaves of 10-weeks old tomato plants as described by Logemann et al. (1987). Aliquots of $4 \mu \mathrm{g}$ total RNA were used for cDNA synthesis with the RevertAid ${ }^{\text {TM }}$ First Strand cDNA Synthesis Kit from Fermentas (St. Leon-Rot, Germany). The qPCR analysis of XylT was carried out using an Mx3000P ${ }^{\mathrm{TM}}$ (Agilent Technologies, Waldbronn, Germany) and SYBR Green (Agilent Technologies) labeling following the standard protocol. A 136 bp cDNA fragment of XylT (Accession Number BG130152) was amplified using the primer XylT_RNAi qPCR f (5'-TTGGAGCCTGAAAATCTTGTAAA-3') and XylT_RNAi qPCR $r$ ( $5^{\prime}$-CATAAC-TGAGAGGGGCTAATA-3'). As an internal standard a $93 \mathrm{bp}$ fragment of the constitutively expressed actin (NCBI-AB199316) was amplified with the primer Actin qPCR $\mathrm{f}$ (5'-TAATCCCAAGGCCAACAG-3') and Actin qPCR r (5'-GAAAGCACAGCCTGGTA-3').

PREPARATION OF TOMATO PROTEIN EXTRACTS AND IMMUNOBLOTTING For Western blotting, fruit samples (approximately $100 \mathrm{mg}$ fresh weight) were homogenized in extraction buffer containing $50 \mathrm{mM}$ Tris- $\mathrm{HCl}$ (pH 6.8), $5 \mathrm{mM} \mathrm{MgCl}, 1 \mathrm{mM}$ EDTA, $1 \mathrm{mM}$ ethylene glycol-bis-( $\beta$-aminoethyl ether)- $N, N, N^{\prime}, N^{\prime}$-tetra acetic acid, $5 \mathrm{mM}$ DTT, $0.1 \mathrm{mM}$ Pefabloc proteinase inhibitor (Roche, Mannheim, Germany), and 15\% glycerol. Samples were cleared by centrifugation $\left(16.200 \mathrm{~g}, 15 \mathrm{~min}\right.$ at $\left.4^{\circ} \mathrm{C}\right)$ and protein content of the supernatant was determined according to the method of Bradford (1976) with the BioRad protein assay solution (BioRad Laboratories, Hercules, CA, USA). An aliquot of the supernatant was immediately mixed with SDS-PAGE loading buffer, denatured at $95^{\circ} \mathrm{C}$ for $10 \mathrm{~min}$ and subjected to a $12.5 \%$ SDS-PAGE under reducing conditions. Separated proteins were blotted onto porablot NCL Nitrocellulose membrane (Macherey-Nagel, Düren, Germany). The blot was blocked in 5\% (w/v) non-fat dry milk in Tris-buffered saline (TBS, 20 mM Tris-HCl, pH 7.6, 200 mM NaCl, 0.1\% (v/v) Tween 20) for $1 \mathrm{~h}$ and afterward incubated in a 1:20000 dilution of the rabbit anti-xylose antibody (Agrisera, Vännäs, Sweden) or the rabbit anti-fucose antibody (Agrisera, Vännäs, Sweden) in TBS supplemented with $0.1 \%$ (v/v) Tween 20 . Horseradish peroxidase (HRP) conjugated anti-rabbit antibody (Sigma-Aldrich, Seelze, Germany) was used as secondary antibody at 1:20000 dilution in TBS-Tween. Peroxidase detection was carried out with enhanced chemiluminescence (ECL) solution I and II.

For IgE immunoblotting the protein extracts and the SDS-PAGE were performed as described for the Western blotting. After blocking in 5\% non-fat dry milk, $0.05 \%$ Tween 20 , TBS pH 7.4 for $2 \mathrm{~h}$, the membrane was incubated with 1:10 diluted patients' sera overnight. Immunostaining of bound $\operatorname{IgE}$ antibodies was performed with a HRP-conjugated goat-anti-human IgE antibody (Sigma-Aldrich) in a 1:20.000 dilution. Visualization was carried out using ECL chemiluminescence.

\section{DEGLYCOSYLATION WITH PNGaSeA}

For peptide- $N$-glycosidase A (PNGaseA) treatment, tomato tissue was extracted with $100 \mathrm{mM}$ HEPES-KOH pH 8, supplemented with $500 \mathrm{mM} \mathrm{NaCl}, 2 \mathrm{mM}$ Pefabloc (Serva, Heidelberg, Germany), and $1 \% \beta$-mercaptoethanol. Four microgram total proteins were freeze dried and afterward boiled for $5 \mathrm{~min}$ in the presence of $0.1 \%(\mathrm{v} / \mathrm{v})$ SDS. After addition of $10 \mathrm{mM}$ sodium citrate buffer $\mathrm{pH} 5.1,0.5 \mathrm{M}$ NaSCN, 0.1 M $\beta$-mercaptoethanol, and 1 mU PNGase A (Roche, 
Mannheim, Germany) the samples were incubated at $37^{\circ} \mathrm{C}$ for $36 \mathrm{~h}$. Samples were separated by SDS-PAGE, blotted on nitrocellulose and subjected to immunoblotting analysis.

\section{MEASUREMENT OF THE VACUOLAR INVERTASE ( $\beta$-FRUCTOFURANOSIDASE) ACTIVITY}

Samples of leaf material were homogenized in liquid nitrogen with extraction buffer. The extracts were centrifuged for $5 \mathrm{~min}$ at $11.000 \mathrm{~g}$ at $4^{\circ} \mathrm{C}$. An aliquot of the resulting supernatant was desalted by centrifugation through Sephadex G-25 medium equilibrated in extraction buffer. The desalted extracts were used for activity measurement of vacuolar invertase as described by Zrenner et al. (1996). Protein concentrations were determined according to Bradford (1976). Vacuolar invertase activity was determined by incubating the extracts at $37^{\circ} \mathrm{C}$ for $90 \mathrm{~min}$. The mixture was neutralized by adding an aliquot of $1 \mathrm{M}$ Tris-HCL, $\mathrm{pH}$ 8.0, and subsequently, the reaction was stopped by heat inactivation at $95^{\circ} \mathrm{C}$ for $5 \mathrm{~min}$. The amount of formed glucose was measured as described by Hajirezaei et al. (2000).

\section{ANALYSIS OF N-GLYCANS BY LIOUID CHROMATOGRAPHY-MASS SPECTROMETRY}

Porous graphitic carbon was used as the stationary phase for separation of the borohydride-reduced glycans as described recently (Pabst et al., 2007; Stadlmann et al., 2008). Detection was performed by electrospray-ionization mass spectrometry on a Q-TOF Ultima Global instrument (Waters). Peak quantification was done with the data-mining software MassMap (MassMap GmbH \& Co. KG, Wolfratshausen, Germany). Relative retention times were used to assure the identity of glycan peaks.

\section{AFFINOBLOTTING}

Glycoproteins which bind concanavalin A (ConA) can be visualized on nitrocellulose after electrophoretic transfer as described above. According to the modified protocol of Faye and Chrispeels (1985) the nitrocellulose sheet was sequentially incubated with Con A and horseradish peroxidase, and the glycoproteins were visualized by staining the peroxidase with diaminobenzidine tetrahydrochloride. The nitrocellulose membrane was incubated without previous fixation steps for $1 \mathrm{~h}$ at room temperature in blocking solution (3\% gelatine in TBS), and to visualize all proteins the blot was incubated at room temperature with gentle agitation in a buffer,

\section{REFERENCES}

Altmann, F. (2007). The role of protein glycosylation in allergy. Int. Arch. Allergy Immunol. 142, 99-115.

Bencurova, M., Hemmer, W., Focke, T., Wilson, I., and Altmann, F. (2004). Specificity of $\operatorname{IgG}$ and $\operatorname{IgE}$ antibodies against plant and insect glycoprotein glycans determined with artificial glycoforms of human transferrin. Glycobiology 14, 457-466.

Bolhaar, S. T., Zuidmeer, L., Ma, Y., Ferreira, F., Bruijnzeel-Koomen, C. A., Hoffmann-Sommergruber, K., van Ree, R., and Knulst, A. C. (2005). A mutant of the major apple allergen, Mal d1, demonstrating hypo-allergenicity in the target organ by double-blind placebo-controlled food challenge. Clin. Exp. Allergy 35, 1638-1644.

Bradford, M. M. (1976). A rapid and sensitive method for the quantitation of microgram quantities of protein utilizing the principle of protein-dye binding. Anal. Biochem. 72, 248-254.

Cianferoni, A., and Spergel, J. M. (2009). Food allergy: review, classification and diagnosis. Allergol. Int. 58, 1-10.

Cox, K., Sterling, J. D., Regan, J. T., Gasdaska, J. R., Frantz, K. K., Peele, C. G., Black, A., Passmore, D., MoldovanLoomis, C., Srinivasan, M., Cuison,

referred to as TBS/gelatine cations, containing TBS, $1 \%$ gelatine, and $1 \mathrm{mM}$ each of $\mathrm{MnCl}_{2}$ and $\mathrm{CaCl}_{2}$, with $25 \mu \mathrm{g} / \mathrm{ml}$ Con A (Roth, Karlsruhe, Germany). After $1 \mathrm{~h}$ the sheet was rinsed twice with TBS and washed three times for 10 min each with TBS containing $0.1 \%$ Tween 20 (TBS/T) supplemented with $1 \mathrm{mM} \mathrm{MnCl}_{2}$ and $\mathrm{CaCl}_{2}$. This step was followed by incubation in TBS/gelatine/cations containing horseradish peroxidase (Sigma) at a final concentration of $50 \mu \mathrm{g} / \mathrm{ml}$. After $1 \mathrm{~h}$ the membrane was rinsed twice with TBS and washed three times for $10 \mathrm{~min}$ each with TBS/T with cations, briefly rinsed in TBS, and immersed in the staining solution $(6 \mathrm{mg}$ diaminobenzidine tetrahydrochloride, $3 \mathrm{mg} \mathrm{CoCl}_{2}$ in $10 \mathrm{mM}$ Tris, $\mathrm{pH}$ 7.6, and $10 \mu \mathrm{l} \mathrm{H}_{2} \mathrm{O}_{2}$ which was freshly prepared immediately before use. Glycoproteins became visible as brown bands within 2 min of incubation. The reaction was stopped with $\mathrm{H}_{2} \mathrm{O}$. Stained membranes were blotted dry, and stored in darkness.

\section{SKIN PRICK TEST}

All investigations were performed in accordance with the ethical principles for medical research involving human subjects documented in the World Medical Association Declaration of Helsinki after ethical approval had been obtained from the local ethics committee (Medical Faculty, Friedrich-Alexander University Erlangen). After written consent of the patients SPT according to Dreborg (1989) were performed. Red tomato fruits from MicroTom WT and different Cvs of XylT-reduced fruits were used for prick-toprick tests in patients. Control prick test solutions (histamine 0.1 and $0.9 \%$ sodium chloride) were purchased from Allergopharma (Reinbek, Germany). Mean wheal diameters were measured after $20 \mathrm{~min}$.

\section{ACKNOWLEDGMENTS}

We thank Dr. Stephan Scheurer for providing sera of Lyc e 2-sensitized patients. We are also grateful to Loïc Faye for advices in glycoprotein detection. In addition, we would like to thank Anja Saalbach and Christiane Börnke for help with tomato transformation and taking care of tissue culture plants and Elke Stein for the infection experiments with Botrytis cinerea. The work was supported by grants So 300/13-1, Ma 1997/3-1 and Ko 1208/18-1 from the German Research Foundation (DFG). None of the authors has a financial relationship with a biotechnology or pharmaceutical manufacturer that has a financial interest in the subject matter or materials discussed in the submitted manuscript.

S., Cardarelli, P. M., and Dickey, L. F. (2006). Glycan optimization of a human monoclonal antibody in the aquatic plant Lemna minor. Nat. Biotechnol. 24, 1591-1597.

Dreborg, S. (1989). EAACI. Skin test for diagnosis of IgE-mediated allergy. Allergy 44(Suppl. 10), 31-37.

Faye, L., and Chrispeels, M. J. (1985) Characterization of N-linked oligosaccharides by affinoblotting with concanavalin A-peroxidase and treatment of the blots with glycosidases. Anal. Biochem. 149, 218-224.

Fitchette-Lainé, A. C., Gomord, V., Cabanes, M., Michalski, J. C., Macary,
M. S., Foucher, B., Cavelier, B., Hawes, C., Lerouge, P., and Faye, L. (1997). $\mathrm{N}$-glycans harboring the Lewis a epitope are expressed at the surface of plant cells. Plant J. 12, 1411-1417.

Foetisch, K., and Vieths, S. (2001). N- and O-linked oligosaccharides of allergenic glycoproteins. Glycoconj. J. 18, 373-390.

Foetisch, K., Westphal, S., Lauer, I., Retzek, M.,Altmann, F., Kolarich, D., Scheurer, S., and Vieths, S. (2003). Biological activity of IgE specific for crossreactive carbohydrate determinants. J. Allergy Clin. Immunol. 111,889-896.

Gomord, V., and Faye, L. (2004). Posttranslational modification of thera- 
peutic proteins in plants. Curr. Opin. Plant Biol. 7, 171-181.

Hajirezaei, M. R., Takahata, Y., Trethewey, R. N., Willmitzer, L., and Sonnewald, U. (2000). Impact of elevated cytosolic and apoplastic invertase activity on carbon metabolism during potato tuber development. J. Exp. Bot. 51, 439-445.

Häweker, H., Rips, S., Koiwa, H., Saloman, S., Saijo, Y., Chinchilla, D., Robatzek, S., and von Schaewen, A. (2010). Pattern recognition receptors require $\mathrm{N}$-glycosylation to mediate plant immunity. J. Biol. Chem. 285, 4629-4636.

Kang, J. S., Frank, J., Kang, C. H., Kajiura, H., Vikram, M., Ueda, A., Kim, S., Bahk, J. D., Triplett, B., Fujiyama, K., Lee, S. Y., von Schaewen, A., and Koiwa, H. (2008). Salt tolerance of Arabidopsis thaliana requires maturation of $\mathrm{N}$-glycosylated proteins in the Golgi apparatus. Proc. Natl. Acad. Sci. U.S.A. 105, 5933-5938.

Karimi, M., Inzé, D., and Depicker, A. (2002). GATEWAY ${ }^{\mathrm{TM}}$ vectors for Agrobacterium-mediated plant transformation. Trends Plant Sci. 7, 193-195.

Kaulfürst-Soboll, H., Mertens, M., Brehler, R., and von Schaewen, A. (2011). Reduction of cross-reactive carbohydrate determinants in plant foodstuff: elucidation of clinical relevance and implications for allergy diagnosis. PLoS ONE 6, e17800. doi: 10.1371/ journal.pone. 0017800

Kondo, Y., Urisu, A., and Tokuda, R. (2001). Identification and characterization of the allergens in the tomato fruit by immunoblotting. Int. Arch. Allergy Immunol. 126, 294-299.

Koprivova, A., Stemmer, C., Altmann, F., Hoffmann, A., Kopriva, S., Gorr, G., Reski, R., and Decker, E. L. (2004). Targeted knockouts of Physcomitrella lacking plant-specific immunogenic N-glycans. Plant Biotechnol. J. 2, 517-523.

Le, L. Q., Mahler, V., Lorenz, Y., Scheurer,S., Biemelt, S., Vieths, S., and Sonnewald, U. (2006). Reduced allergenicity of tomato fruits harvested from Lyc e 1 silenced transgenic tomato plants. J. Allergy Clin. Immunol. 118, 1176-1183.

Le, L. Q., Mahler, V., Scheurer, S., Foetisch, K., Braun, Y., Weigand, D., Enrique, E., Lidholm, J., Paulus, K. E., Sonnewald, S., Viehts, S., and Sonnewald, U. (2010). Yeast profilin complements profilin-deficiency in transgenic tomato fruits and allows development of hypoallergenic tomato fruits. FASEB J. 24, 4939-4947.

Leigh, R. A., Rees, T., Fuller, W. A., and Banfield, J. (1979). The location of acid invertase activity and sucrose in the vacuoles of storage roots of beetroot (Beta vulgaris). Biochem. J. 178, 539-547.

Lerouge, P., Bardor,M.,Pagny, S., Gomord, V., and Faye, L. (2000). N-glycosylation of recombinant pharmaceutical glycoproteins produced in transgenic plants towards an humanisation of plant N-glycans. Curr. Pharm. Biotechnol. 1, 347-354.

Ling, H. Q., Kriseleit, D., and Ganal, M. W. (1998). Effect of ticarcillin/potassium clavulanate on callus growth and shoot regeneration in Agrobacteriummediated transformation of tomato (Lycopersicon esculentum Mill). Plant Cell Rep. 17, 843-847.

Logemann, J., Schell, J., and Willmitzer, L. (1987). Improved method for the isolation of RNA from plant tissues. Anal. Biochem. 163, 16-20.

Mahler, V., Gutgesell, C., Valenta, R., and Fuchs, T. (2006). Natural rubber latex and hymenoptera venoms share ImmunoglobinE-epitopes accounting for cross-reactive carbohydrate determinants. Clin. Exp. Allergy 36, 1446-1456.

Mari, A. (2002). IgE to cross-reactive carbohydrate determinants: analysis of the distribution and appraisal of the in vivo and in vitro reactivity. Int. Arch. Allergy Immunol. 129, 286-295.

Melo, N. S., Nimtz, M., Conradt, H. S., Fevereiro, P. S., and Costa, J. (1997). Identification of the human Lewis a carbohydrate motif in a secretory peroxidase from a plant cell suspension culture (Vaccinium myrtillus L.). FEBS Lett. 415, 186-191.

Mertens, M., Amler, S., Moerschbacher, B. M., and Brehler, R. (2010). Crossreactive carbohydrate determinants strongly affect the results of the basophil activation test in hymenopteravenom allergy. Clin. Exp. Allergy 40, 1333-1345.

Mueller, H.L. (1966). Diagnosis and treatment of insect sensitivity. J. Asthma Res. 3, 331-333.

Pabst, M., Bondili, J. S., Stadlmann, J., Mach, L., and Altmann, F. (2007). Mass + retention time $=$ structure: a strategy for the analysis of $\mathrm{N}$-glycans by carbon LC-ESI-MS and its application to fibrin N-glycans. Anal. Chem. 79, 5051-5057.

Roth, B. M., Pruss, G. J., and Vance, V. B. (2004). Plant viral suppressors of RNA silencing. Virus Res. 102, 97-108.

Saint-Jore-Dupas, C., Faye, L., and Gomord, V. (2007). From planta to pharma with glycosylation in the toolbox. Trends Biotechnol. 25, 317-323.

Scheurer, S., and Sonnewald, S. (2009). Genetic engineering of plant food with reduced allergenicity. Front. Biosci. 14, 59-71.
Scholes, J., Bundock, N., Wilde, R., and Rolfe, S. (1996). The impact of reduced vacuolar invertase activity on the photosynthetic and carbohydrate metabolism of tomato. Planta 200, 265-272.

Stadlmann, J., Pabst, M., Kolarich, D. Kunert, R., and Altmann, F. (2008). Analysis of immunoglobulin glycosylation by LC-ESI-MS of glycopeptides and oligosaccharides. Proteomics 8, 2858-2871.

Strasser, R., Altmann, F., Mach, L., Glössl, J., and Steinkellner, H. (2004), Generation of Arabidopsis thaliana plants with complex $\mathrm{N}$-glycans lacking $(\beta 1,2$-linked xylose and core $(\alpha 1,3$ linked fucose. FEBS Lett. 561, 132-136.

Strasser, R., Castilho, A., Stadlmann, J., Kunert, R., Quendler, R., Gattinger, P., Jez, J., Rademacher, T., Altmann, F., Mach, L., and Steinkellner, H. (2009). Improved virus neutralization by plant-produced anti-HIV antibodies with a homogeneous $\beta 1,4$ galactosylated $\mathrm{N}$-glycan profile. J. Biol. Chem. 284, 20479-20485.

Strasser, R., Stadlmann, J., Schähs, M., Stiegler, G., Quendler, H., Mach, L. Glössl, J., Wterings, K., Pabst, M., and Steinkellner, H. (2008). Generation of glyco-engineered Nicotiana benthamiana for the production of monoclonal antibodies with a homogeneous human-like N-glycan structure. Plant Biotechnol. J. 6, 392-402.

Szittya, G., Silhavy, D., Molnar, A., Havelda, Z., Lakatos, L., Banfalvi, Z., and Burgyan, J. (2003). Low temperature inhibits RNA silencing-mediated defence by the control of siRNA generation. EMBO J. 22, 633-640.

Tretter, V., Altmann, F., Kubelka, V., März, L., and Becker, W. M. (1993). Fucose $\alpha 1,3$-linked to the core region of glycoprotein $\mathrm{N}$-glycans creates an important epitope for IgE from honeybee venom allergic individuals. Int Arch. Allergy Immunol. 102, 259-266.

Tretter, V., Altmann, F., and März, L. (1991). Peptide-N4-(N-acetyl-betaglucosaminyl)asparagine amidase $\mathrm{F}$ cannot release glycans with fucose attached alpha $1-3$ to the asparaginelinked $\mathrm{N}$-acetylglucosamine residue. Eur. J. Biochem. 199, 647.

van der Veen, M. J., van Ree, R., Aalberse, R. C., Akkerdaas, J., Koppelman, S. J, Jansen, S. M., and van der Zee, J. S. (1997). Poor biological activity of cross-reactive IgE directed to carbohydrate determinants of glycoproteins. J. Allergy Clin. Immunol. 100, 327-334. van Ree, R., Cabanes-Macheteau, M. Akkerdaas, J., Milazzo, J. P., LoutelierBourhis, C., Rayon, C., Villalba, M., Koppelman, S., Aalberse, R. Rodriguez, R., Faye, L., and Lerouge, P. $(2000)$. $\beta(1,2)$-Xylose and $\alpha(1,3)$ -
Fucose residues have a strong contribution in IgE binding to plant glycoallergens. J. Biol. Chem. 275, 11451-1148.

von Schaewen, A., Sturm, A., O'Neill, J., and Chrispeels, M. (1993). Isolation of a mutant Arabidopsis plant that lacks $\mathrm{N}$-acetyl glucosaminyl transferase I and is unable to synthesize Golgimodified complex N-linked glycans. Plant Physiol. 102, 1109-1118.

Westphal, S., Kolarich, D., Foetisch, K., Lauer, I.,Altmann, F., Conti, A., Crespo, J. F., Rodriguez, J., Enrique, E., Vieths, S., and Scheurer, S. (2003). Molecular characterization and allergenic activity of Lyc e 2 (beta-fructofuranosidase), a glycosylated allergen of tomato. Eur. J. Biochem. 270, 1327-1337.

Wilson, I. B. H., and Altmann, F. (1998). Structural analysis of $\mathrm{N}$-glycans from allergenic grass, ragweed and tree pollens: core $\alpha 1,3$-linked fucose and xylose present in all pollens examined. Glycoconj. J. 15, 1055-1070.

Zrenner, R., Schüler, K., and Sonnewald, U. (1996). Soluble acid invertase determines the hexose-to-sucrose ratio in cold-stored potato tubers. Planta 198 , 246-252.

Zuidmeer, L., van Leeuwen, W. A., Kleine Budde, I., Breiteneder, H., Ma, Y., Mills, C., Sancho, A. I., Meulenbroek, E. J., van de Weg, E., Gilissen, L., Ferreira, F., Hoffmann-Sommergruber, K., and van Ree, R. (2006). Allergenicity assessment of apple cultivars: hurdles in quantifying labile fruit allergens. Int. Arch. Allergy Immunol. 141, 230-240.

Conflict of Interest Statement: The authors declare that the research was conducted in the absence of any commercial or financial relationships that could be construed as a potential conflict of interest.

Received: 18 May 2011; paperpending published: 10 July 2011; accepted: 10 August 2011; published online: 29 August 2011.

Citation: Paulus KE, Mahler V, Pabst M, Kogel K-H, Altmann $F$ and Sonnewald $U$ (2011) Silencing $\beta 1,2-x y l o s y l t r a n s f e r a s e$ in transgenic tomato fruits reveals $x y$ lose as constitutive component of IgE-binding epitopes. Front. Plant Sci. 2:42. doi: 10.3389/fpls.2011.00042

This article was submitted to Frontiers in Plant Biotechnology, a specialty of Frontiers in Plant Science.

Copyright (๑) 2011 Paulus, Mahler, Pabst, Kogel, Altmann and Sonnewald. This is an open-access article subject to a nonexclusive license between the authors and Frontiers MediaSA, which permits use, distribution and reproduction in other forums, provided the original authors and source are credited and other Frontiers conditions are complied with. 